\title{
Constructing the Norte Grande: Chilean Infrastructure in the Northern Border Region, 1915-1929
}

William Cohoon

Portland State University

Follow this and additional works at: https://pdxscholar.library.pdx.edu/mcnair Let us know how access to this document benefits you.

\section{Recommended Citation}

Cohoon, William (2013) "Constructing the Norte Grande: Chilean Infrastructure in the Northern Border Region, 1915-1929," PSU McNair Scholars Online Journal: Vol. 7: Iss. 1, Article 12.

https://doi.org/10.15760/mcnair.2013.24 
Portland State University McNair Research Journal 2013

Constructing the Norte Grande:

Chilean Infrastructure in the Northern Border Region, 1915-1929

\author{
by \\ William Cohoon \\ Faculty mentor: \\ Professor Friedrich E. Schuler
}

Cohoon, W. Constructing the Norte Grande: Chilean Infrastructure in the Northern Border Region, 1915-1929. Portland State University McNair Scholars Online Journal, Vol. 7, 2013 
Table of Contents

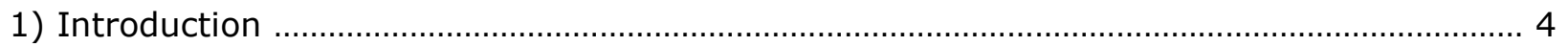

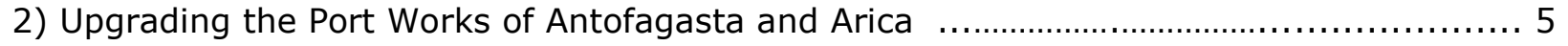

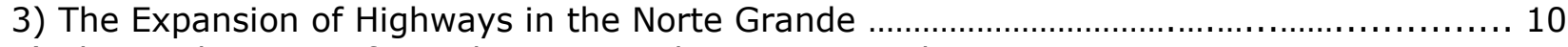

4) The Implications of Development in the Norte Grande ................................................. 13

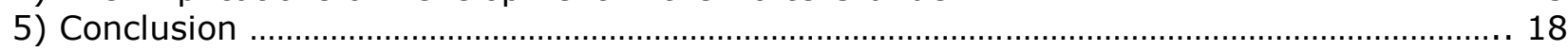

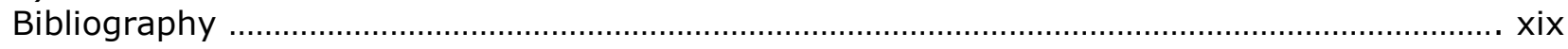


Maps, Photos, and Tables

Figure I: Map of Norte Grande and Norte Chico ............................................................ 4

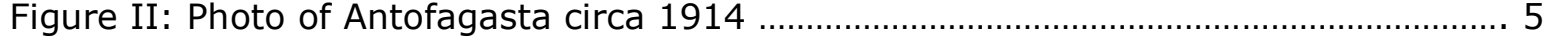

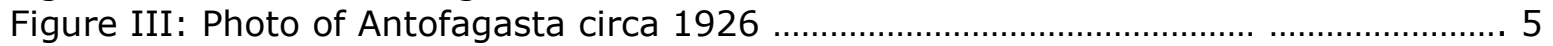

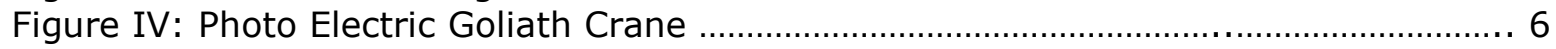

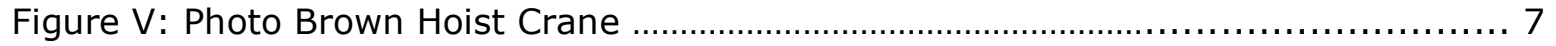

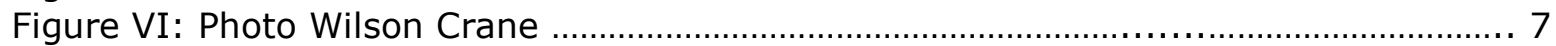

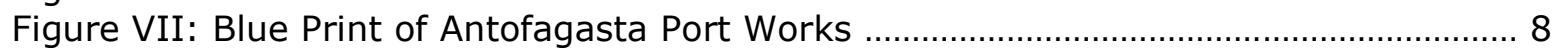

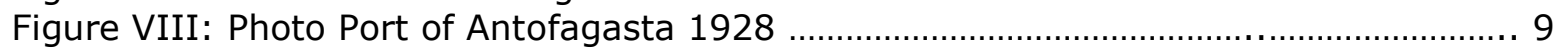

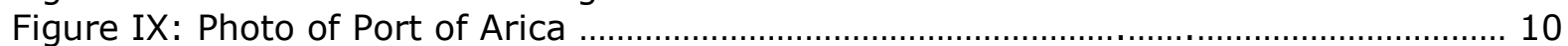

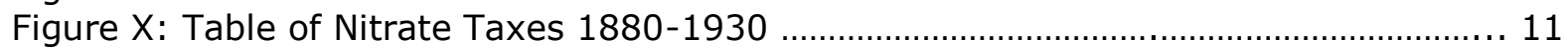

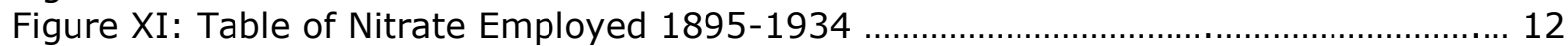

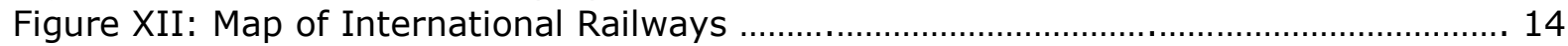

Figure XIII: Photo of Transferring Materials at Antofagasta ....................................... 15

Figure XIV: Map of Peru and Bolivia (Sama River) ..................................................... 17 


\section{Introduction}

The norte grande (Fig. 1), the far north, is comprised of the provinces of Antofagasta and

Tarapacá. Acquired after the War of the Pacific, 1878 to 1883, this region increased Chile by almost a third, ${ }^{1}$ and possessed valuable mineral resources, such as sodium nitrate and guano. With these resources at Chile's disposal the government realized the norte grande, despite several decades of Great Britain's entrepreneurship, possessed limited infrastructure. This included, but was not limited to, the ports of Antofagasta and Arica not being up-to-date with improved technology to handle modern cargo loads, as well as Chile not being able to respond militarily to potential hostilities with Bolivia and Peru, attributed to the Tacna-Arica dispute.

\footnotetext{
${ }^{1}$ Brian Loveman, Chile; The Legacy of Hispanic Capitalism, (New York and Oxford: Oxford University Press, 2001$), 147$.
} 


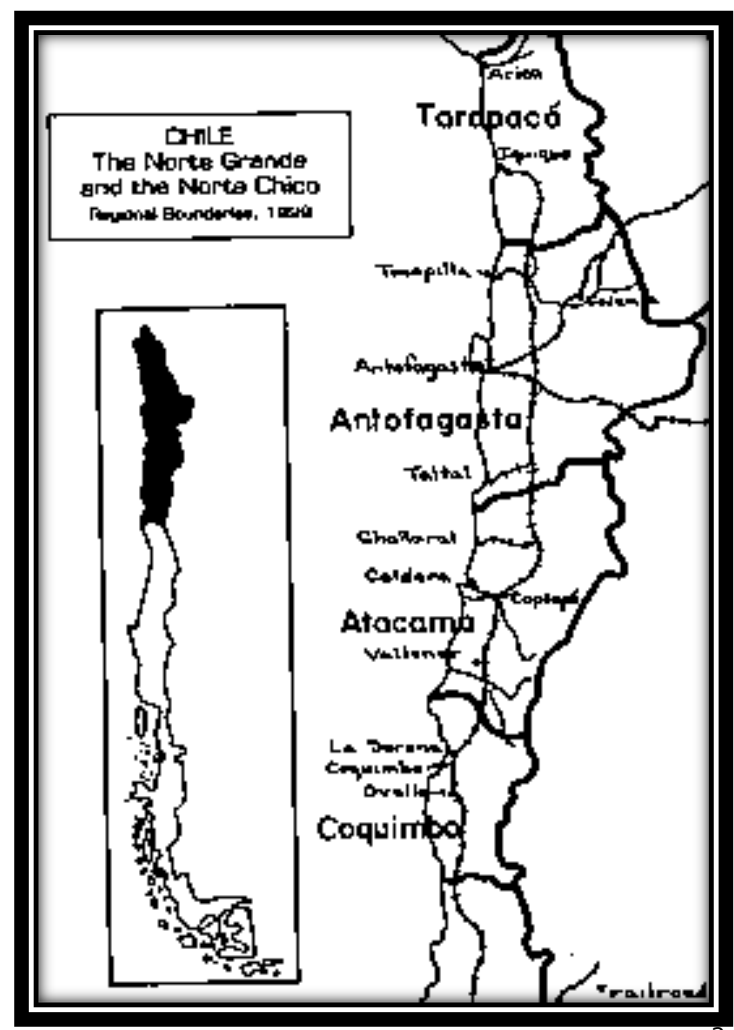

To address these problems Presidents Arturo Allesandri Palma and Carlos Ibañez del Campo began constructing public works projects in the territory. Many of the infrastructure projects in the norte grande began during the presidency of Arturo Alessandri, where he requested "legislation passed by the parliament on labor .... public works .... military and tax reform. ${ }^{1}$ But as Fredrick M. Nunn has demonstrated, in his seminal work Chilean Politics 1920-1931; The Honorable Mission of the Armed Forces, Alessandri encountered many difficulties in this desire to improve the wellbeing of Chileans. This in part is due to the increased use of synthetic nitrates, invented by Germany during World War I, which contributed to inconsistent nitrate production during the 1920 s. This created a huge burden on the Chilean state to fund these projects, as a large portion of tax revenue came from nitrate. President Allesandri was unable to see most of these works to their completion due to the complicated relationship between the president and the congress, all of which contributed to a coup in 1925.

Figure 1: Norte Grande and Norte Chico $^{2}$

Yet literature on the norte grande emphasizes not only the political turmoil in the Chilean government, but also the tenuous relationship with Peru, and Bolivia. For instance, the works of William Jefferson Davis, the Tacna and Arica: an Account of the Chile-Peru Boundary Dispute and the Arbritrations by the United States, and William E. Skuban's Lines in the Sand: Nationalism and Identity on the Peruvian-Chilean Frontier highlight the relationship between these three countries. In addition to these collected works, several pieces address the nitrate industry and its subsequent development, however, the importance is placed on the numerous railways in the territory, such as Harlod Blakemore's From the Pacific to La Paz: the Antofagasta (Chili) and Bolivia Railway Company, 1888-1988. Although Brian Loveman's Struggle in the Countryside Politics and Rural Labor in Chile, 1919-1973 at times discusses the "expansion of road networks," but Loveman uses this to depict the movement of rural laborers to and from various locations in Chile. ${ }^{3}$ However, this article incorporates previously underutilized documents from the National Archives in Washington D.C. to demonstrate the processes and progression of construction in the cities of Antofagasta and Arica.

\section{Upgrading the Port Works of Antofagasta and Arica}

When Chile acquired the provinces of Tarapacá and Antofagasta they inherited not only valuable nitrate resources, but also ports that had been part of the nitrate industry for several decades prior to the War of the Pacific. Thus, as a subsequent result, the enhancement of port works became evident to the state. According to Consul Stewart E. McMillin prior to 1910 "no port construction, in the proper sense of the word, was carried out in Chile." Despite such a sentiment, the Port of Antofagasta moved a net registered tonnage of close to 7.1 million through 3,209 ships

\footnotetext{
2 Ibid, 18.

${ }^{3}$ Brian Loveman, Struggle in the Countryside: Politics and Rural Labor in Chile, 1919-1973, (Bloomington: Indiana University Press, 1972), 189.
} 
in 1911. For a comparison the well-known port of Valparaíso handled a net registered tonnage of 5.06 million, while working with only 2,491 vessels. The Chilean state decided on the ports of Valparaiso, Antofagasta, and Arica as the final order of importance. Valparaiso garnered more attention from the government due to proximity to Santiago, and the high price of improvements, a result of the engineers' anticipated difficulties in construction. ${ }^{4}$

Nonetheless, such optimism led the city of Antofagasta to procure a $£ 200,000$ loan from England prior to the outbreak of World War I. The municipality used the loan from Great Britain to fund a variety of projects in the city. These tasks included tree planting, "construction of a model market," a "crematory furnace for garbage," "modern means for the removal of garbage," and new buildings for public service workers at Mejillones. However, the administrators of Antofagasta allocated $£ 136,000$ alone on "pavement of the streets (Fig. $2 \& 3$ )."

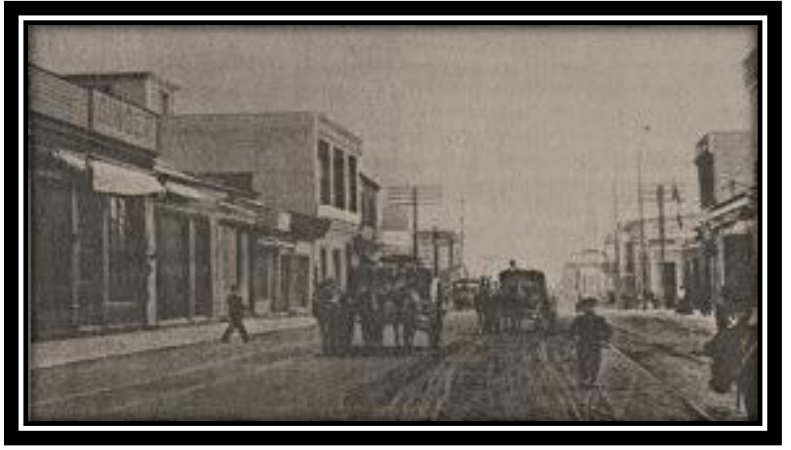

Figure 2: Photo Antofagasta Dirt Streets ${ }^{5}$

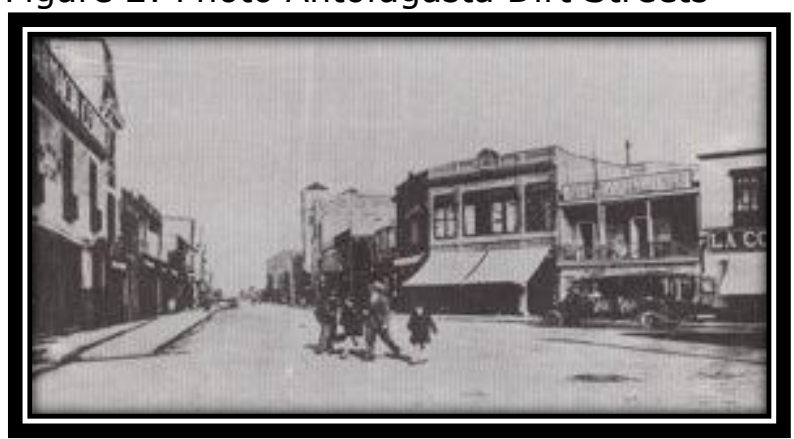

The streets located closest to the docks, and railroads, used "hard stone blocks," due to the high degree of traffic in the area. Such an improvement should not be underestimated when compared with the industrialized nations of the United States or Great Britain. With paved streets, this permitted year round use by the population of the city, not to mention the ability to provide improved transportation to the region in addition to moving heavy goods and people within the city. This is demonstrated by the construction of sidewalks in the city, which was included in the cost for the street paving, as well as a proposed electric streetcar system. ${ }^{1}$ These various developments would contribute to increasing the movability people to better aid the further enhancement of the port stipulated by the Commission of Ports in 1911.

Subsequently, in 1916, an additional bill for the improvement of port works in Antofagasta received approval by the Chilean government. The decree

Figure 3: Photo Antofagasta Paved Streets

stipulated contracts for the enhancement of the harbor should come from public proposals over the next eighteen month, were to include the maximum price with a cap of $£ 1.7$ million, and contractors would be paid with government bonds. This condition emphasized the funds were to be used solely for construction purposes, "federal inspections, and the expenses in Article 5." The costs alluded to included three hundred gold pesos of eighteen pence that were to be used "in the preliminary expenses of the construction of the port and of the railway branch which will unite it with the Longitudinal Railway." Furthermore, in Article 4 of the mandate, the president of Chile stated that private or municipal ownership of lands, and materials needed for the development of the port according to the approved plan were declared for public use. Ultimately, the Chilean president had the final word in the conservation of harbors, and other mandates pertaining to the wellbeing of the port. ${ }^{6}$

\footnotetext{
${ }^{4}$ National Archives of the United States (NAUS), RG59, Internal Affairs of Chile (M5144), reel 15, 825.1561/3, "Chilean Port Improvement Works," Consul Stewart E. McMillin to Division of Latin American Affairs Department of State, August 21-25, 1924.

5 Juan Panades Vargas, Floreal Recabbren Rojas, Antonio Obilinovic Arrate, and Alfonso Calderon Squadritto. Antofagasta: Una Historia en Imágenes, (Antofagasta: Universidad de Chile, 1979). Figure 1 is a picture from 1914 and was found on page 22, while Figure 2 was taken in 1926 and can be located on page 21.
} 
However, construction on the breakwater in Antofagasta did not begin until after World War I in 1919. Vice Consul Ben C. Matthews reported in 1922 that roughly 450 workers throughout the city were employed on various projects to enhance the port city. In addition to this, workers had begun the process of making "huge cement blocks which [were] used with rock in constructing the jetty." The electrically run Goliath Crane (Fig. 4) had a capability to lift approximately sixty tons and was used to move the blocks for the jetty, of which there were 250 yards constructed. This crane moved the blocks to the barges, which in turn transported them and dumped the blocks on the breakwater. $^{7}$ Baburizza Lagarrigue y Cia of Playa Blanca, Antofagasta received the bid to manage the construction process, and was "the first port development company organized in Chile." ${ }^{8}$ The company oversaw the completion of the wharf for the lighters and barges outside of the breakwater, while the dock inside of the mole was close to being finished. ${ }^{9}$

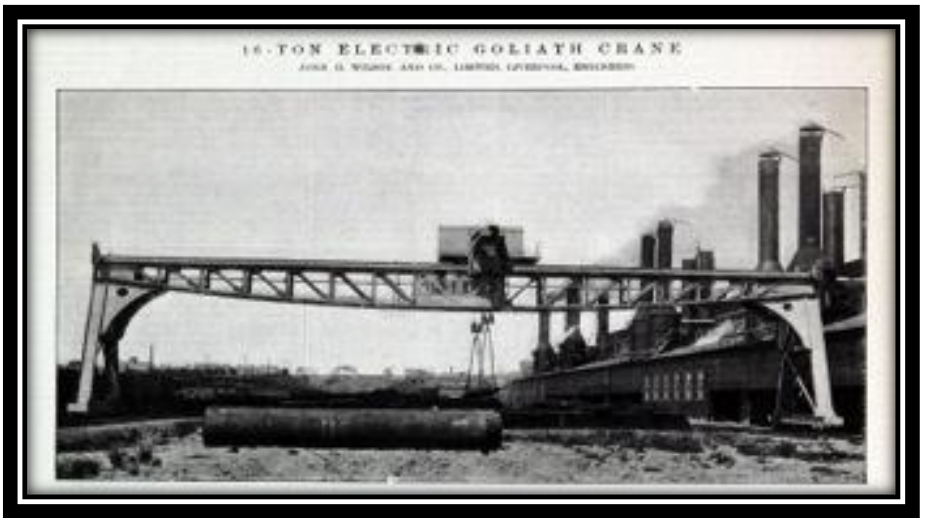

In addition to the tonnage of freight moved in 1911, Antofagasta's location made this desirable port for development, attributed to the bay being in a crescent moon like shape, which according to the report from Consul Stewart McMillin would allow future construction at the fraction of the current price. Eduardo Reyes Cox, working for Baburizza Lagrrigue y Cia, continued the construction of port works at Antofagasta, with an estimated time of completion of 1925 ,

Figure 4: Goliath Crane ${ }^{10}$

where the mole would measure 4,816 feet at cost of $\$ 8.2$ million, with the prospect of second mole at 1,640 feet. Further concepts proposed 7,545 feet of "landing piers for steamers," wharf space at almost 9.2 million cubic feet, and railways connecting to warehouses, which were projected to be completed by the end of 1927 . The approximated capacity of the wharf presented the following: protected water surface of 30 hectares (74.13 acres), an accompanying land surface, of 40 hectares ( 98.84 acres), and an annual port movement 7.6 million registered net tons.

\footnotetext{
${ }^{6}$ NAUS, RG59, M5144, reel 15, 825.156/33, "Approval of Law Providing for the Construction of Port Works at Antofagasta," Consul Thomas W. Voetter to Index Bureau Department of State, September 8, 1916.

${ }^{7}$ Ibid, 825.156/38, "Port Works at Antofagasta, Chile," Vice Consul Ben C. Matthews to Division of Latin American Affairs Department of State, June 23, 1922.

${ }^{8}$ Ibid, 825.1561/3, "Chilean Port Improvement Works," Consul Stewart E. McMillin to Division of Latin American Affairs Department of State, August 21-25, 1924.

${ }^{9}$ Ibid, 825.156/38, "Port Works at Antofagasta, Chile," Vice Consul Ben C. Matthews to Division of Latin American Affairs Department of State, June 23, 1922.

10 Pictures from a reputable website, or archives, at this appoint appear scarce. To better provide the reader with the differences and preferences of the workers at the docks, it is essential to provide the visual support of the contrasts. Accessed June 20, 2012. http://www.gracesguide.co.uk/John_H._Wilson_and_Co.
} 


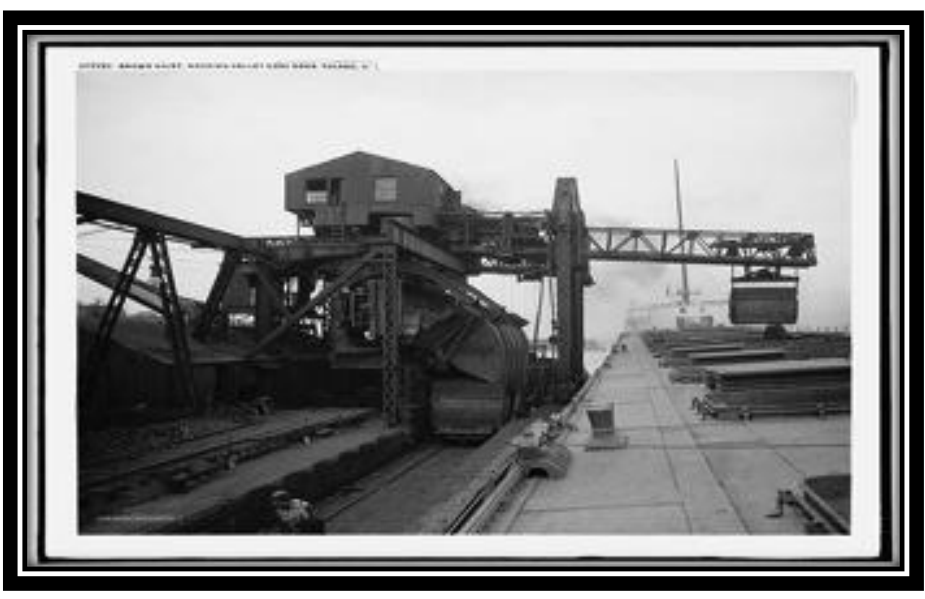

Figure 5: American Brown Hoist Crane ${ }^{11}$ 20.TON LOCOMOTIVK BRKAKDOWN CRANK

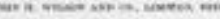

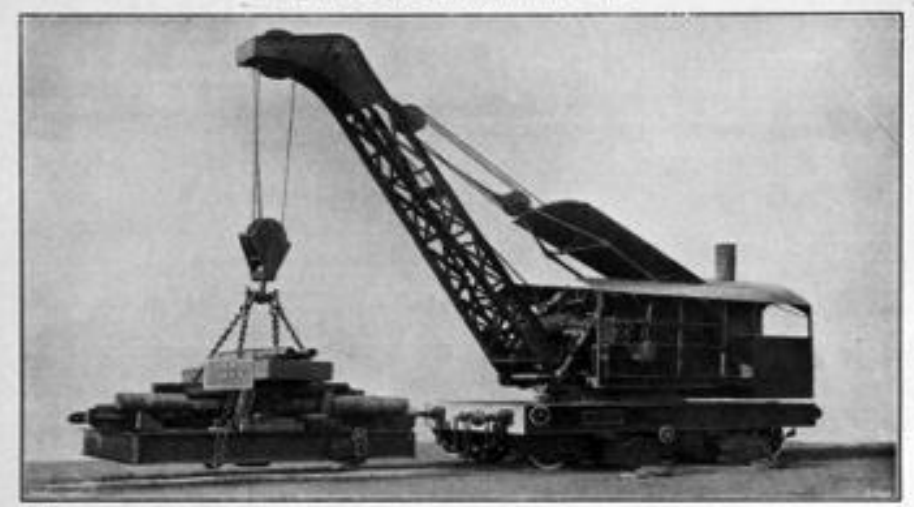

By November 7 approximately 659 feet of the breakwater and underwater foundation were finished. This was mostly accomplished through an investment of $£ 600,000$. The investment included the purchase of ten cranes with capabilities to lift up to fifteen tons to a maximum height of close to twenty feet. Of the ten, four were Brown Hoist type of cranes(Fig. 5) from the United States and the remaining were Wilson (Fig. 6) cranes originating from England. The head foreman declared the Brown Hoist "to be superior to the English 'Wilson' cranes." This is attributed to the fuel efficiency of the American made crane.

Furthermore, machinery from the United States consisted of rock drills, crane compressors, and tools. The new equipment was to also be used in the rock quarry located on the periphery of the Antofagasta, and had "a producing capacity of 2,500 to 3,000 tons of rock daily." These materials were transferred through the city by seven English locomotives, and two hundred cars. Five hundred men worked at the time of the report. The workers housing had been completed, which included a school, theater, and medical service. These materials were

Figure 6: English Wilson Crane ${ }^{12}$

transferred through the city by seven English locomotives, and two hundred cars. Five hundred men worked at the time of the report. The workers housing had been completed, which included a school, theater, and medical service. Such services were free to all workers, and their families. ${ }^{13}$ In 1923, the Chilean Minister in London reported that a loan of $£ 500,000$ through the Anglo-South American Bank Limited had been procured to continue work on the port. The loan was designated to complete the breakwater and to begin construction on the new pier, of which " $£ 100,000$ " was "immediately available." ${ }^{14}$

Although construction in Antofagasta steadily progressed, Consul Stewart E. McMillin reported that there was "urgent" sense to construct the jetty. Antofagasta's location "protected it on the north," but because the harbor is "open on the south and west" winds from these directions created a variety of challenges, such as stronger currents. These annoyances made "the anchorage ground unfavorable." Thus making a structure for docking safely became evident. Furthermore, the rocky bottom of the port and depth, at times approaching thirty meters, illustrates the trials engineers faced. In addition to these depths of water, the engineers had to take into consideration waves that at times measure up to "6 meters in height." Despite these issues, the proposed blue print included

\footnotetext{
${ }^{11}$ Library of Congress, Digital Photo Files, Accessed June 20,2012. http://www.loc.gov/pictures/resource/det.4a24767/.

${ }^{12}$ Accessed June 20, 2012. http://www.gracesguide.co.uk/John_H._Wilson_and_Co.

13 NAUS, RG59, M5144, reel 15, 825.156/40, "The Port Works of Antofagasta, Chile," Consul Class 6 Stewart E. McMillin to Index Bureau Department of State, November and December 1922.

${ }^{14}$ Ibid, 825.156/47, "The Port Works of Antofagasta, Chile," Consul Stewart E. McMillin to Division of Latin American Affairs State Department of State, November 10, 1923.
} 
a jetty measuring 1450 meters in length that would "close the port on the south and west." The first 240 meters of the newly constructed jetty consisted of "rock-fill type protected by 60-ton blocks placed one upon the other." Due to the fluctuation in the bay, the pouring of concrete proved difficult. This contributed to the engineers for the upper part of the jetty to notch the blocks "so as to give the jetty more coalescence." 15

Despite the complications with construction, and the anxieties that arose, the port works development at Antofagasta was sustained during the year 1924. This timeframe saw the foundation of the work contract extended from 307.28 to 726.80 meters, with roughly and additional 725.08 meters to be constructed for the mole to be completed. By the end of the year approximately 3,817 sixty-ton cement blocks were built for the extension of the mole. At this point the rock quarry produced 548,000 tons of rock with a total to date of 2,143,000 tons. However, a strong tidal wave struck the mole in June, causing damage in the first section. By the end of year, workers finished the repairs and conducted further enhancements to various structures at an additional cost of 115,000 pesos. Port Commission approved widening the project as outlined by the Direccion Fiscal, thus providing "1,440 meters of boat landings and a mole which is to close the bay on the north, leaving only and entrance of 175 meters. ${ }^{16}$

On January 15, 1927 Baburizza Lagarrigue and Company received a disbursement of 68,067,900 pesos, or $\$ 8,168,148$, for finishing the long breakwater that measured 1,209 meters. In order to accommodate the new equipment for port operations, the construction of the new port works necessitated "a great deal of filling in order to provide space for the operation of machinery, sidings and other port devices." Thus providing an area of 31.5 hectares protected from ocean, and another 31 hectares of land was reclaimed from the sea. The geography and geology of the coast created difficulties, as the "shore line is entirely of a hard granite formation, of volcanic origin; at no place could a shovel

be used."

Subsequently, in order to provide an adequate depth for the ships to dock, the contractors blasted the shoreline. El Melon, near Valparaiso, provided concrete for the breakwater, and rock quarried from an area just south of Antofagasta was used to construct the large blocks for the construction

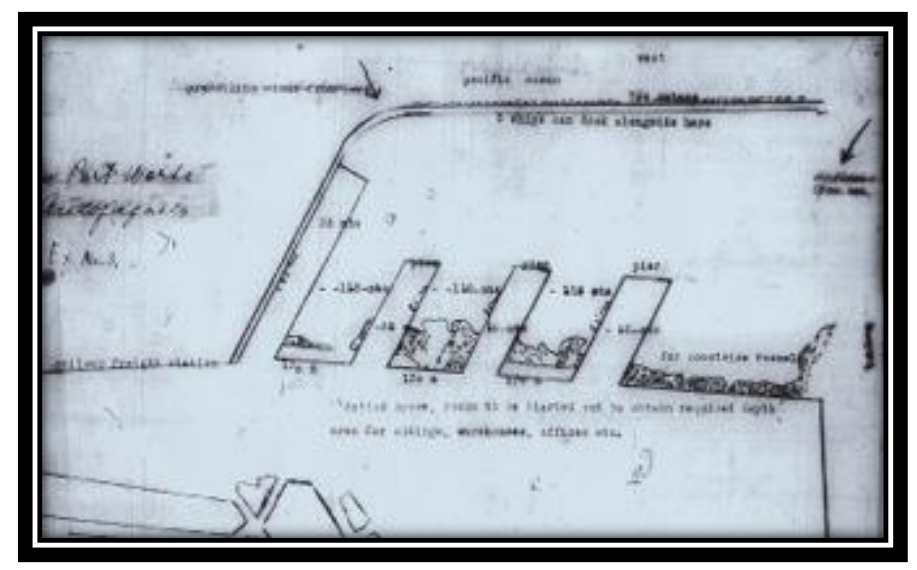

of the breakwater. At this time the ships "tied up inside the breakwater, especially passenger vessels, as the sea is too rough to permit safe landing from the harbor." Although typical, losses of "heavy cargoes," which the barges and lighters controlled, occurred. The terms for another contract called for the construction of an additional breakwater at an estimated $90,867,328,80$ pesos, or $\$ 10,904,079.48$. The proposed date of completion was 1929. Furthermore, the contract called for the construction of "three piers (Fig. 7),

Figure 7: Blue Print of Antofagasta Piers

deepening of the water near shoreline, customs stations, and other-port equipment, such as cranes (Fig. 8)." According to Consul George D. Hopper these enhancements made "Antofagasta ... the only well protected harbor for large vessels at any port from Guayaquil [Ecuador] to Buenos

\footnotetext{
${ }^{15}$ Ibid, 825.156/3, "Chilean Port Improvement Works," Consul Stewart E. McMillin to Division of Latin American Affairs Department of State, August 21-25, 1924.

${ }^{16}$ Ibid, 825.156/52, "Advance in Construction of the Antofagasta Port Works for the year 1924," Consul Stewart E. McMillian to the Department of State, January 24, 1925.
} 
Aires. ${ }^{17}$ Although not mentioned as frequently in the various diplomatic exchanges, the Port of Arica received a similar upgrade in port works.

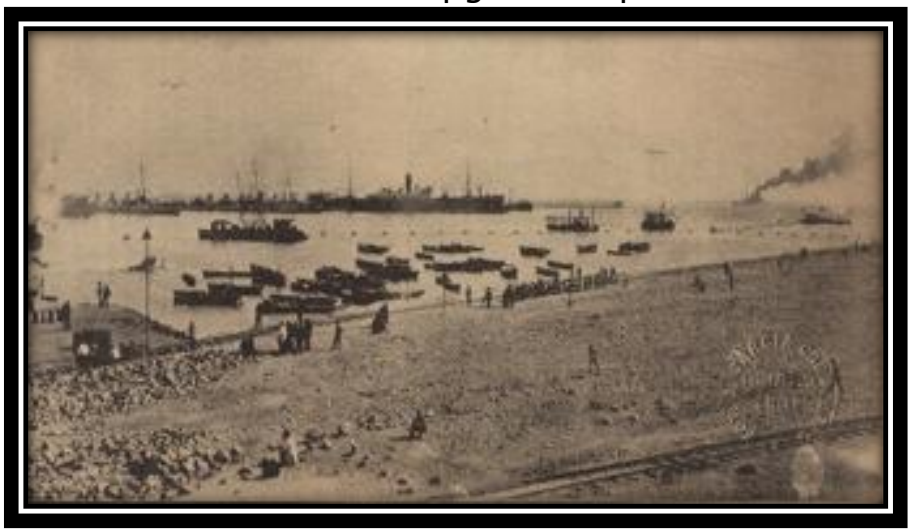

The Port of Arica was highlighted in the Commission of Ports report in 1911. The commission, as previously mentioned, placed Arica third on the list of important ports to the future of Chile, behind Valparaiso and Antofagasta. This sentiment is attributed to the movement of material goods in the port, which amounted to a net registered tonnage of close to 3.6 million, about half of the materials Antofagasta handled that year. In addition to the transferring of cargo, 1,456 ships moved through the port of Arica at the

Figure 8: Photo of Antofagasta Ships and Cranes ${ }^{18}$

time of the commission's report. The hope of the Commission of Ports was that with the proposed improvements to the port, Arica would move 450,000 tons of cargo annually. ${ }^{19}$

Yet, a proposal for the enhancement of the docks at Arica was not noted until 1921, when Consul Homer Brett reported the Chilean government appropriated 1.7 million pesos for the construction of a new dock at Arica. The agreement was to be completed by the Ministero de Obraras Publico, led by Señor Don Guillermo Aguero, "without the intervention of a contractor." The old piers in the port of Arica were to be the models for the new blueprints for the construction of the new docks. In addition to the improvement of the docks, three to four new cranes were required to accommodate such construction. It was estimated that the lifting capacity should be between twenty-five and fifty tons. ${ }^{20}$

Discussions on the development of the port had occurred for numerous years, yet never moved beyond the proposal stage. Despite the appropriation of funds for the building of the new pier in 1921, construction did not begin until 1922, when the engineers arrived. The Philip Holzman construction firm received the bid for building of the pier, who provided "the engineers, mechanics, and skilled artisans, while the other work will be preformed by Chilean laborers, and altogether about four hundred men will be employed." It is unclear at this point whether or not Señor Guero oversaw any construction of the port. Nonetheless, completion of the dock was estimated at two years, at cost of 3.05 million pesos and 200,000 gold pesos of eighteen pence. The proposal stated an "irregular triangle protruding into the sea" that "will cover 17,280 square meters of ground." The shoreline was to be the primary foundation for the port. ${ }^{21}$

\footnotetext{
${ }^{17}$ Ibid, 825.1561/4, "New Port Works at Antofagasta, Chile," Consul George D. Hopper to Index Bureau Department of State, June 14, 1927.

${ }^{18}$ Isaac Arce Ramírez, Narraciones Históricas de Antofagasta, (Antofagasta, 1930), 469. This picture is of the almost completed work at the time, early 1929.

${ }_{19}$ NAUS, RG59, M5144, reel 15, 825.1561/3, "Chilean Port Improvement Works," Consul Stewart E. McMillin to Division of Latin American Affairs Department of State, August 21-25, 1924.

${ }^{20}$ Ibid, 825.1561, "New Pier at Arica, Chile," Consul Homer Brett to State Department January 21, 1921.

${ }^{21}$ Ibid, 825.1561/2, "Harbor Improvement at Arica, Chile," Consul Egmont C. von Tresckow to State Department, March 30, 1922.
} 


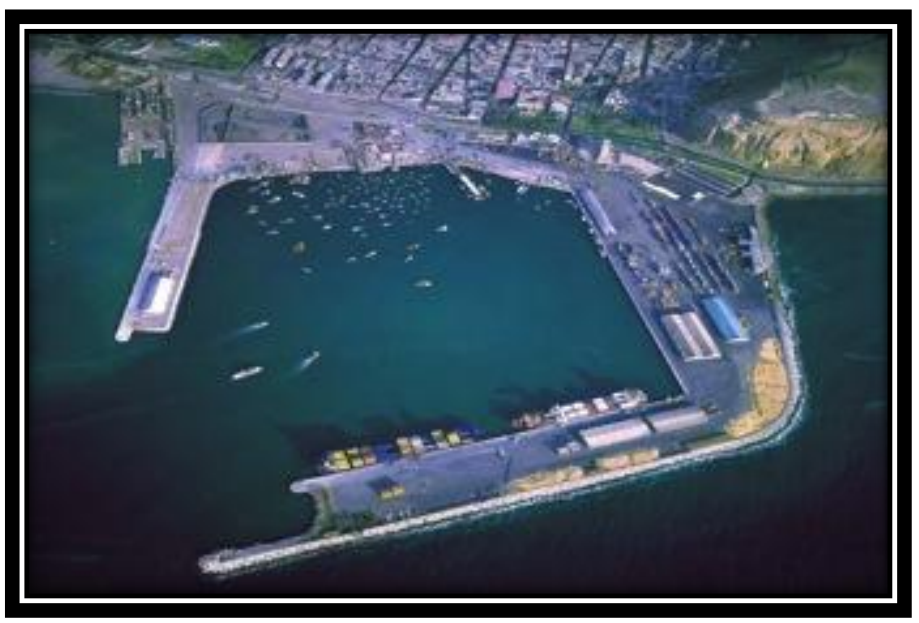

Figure 9: Port of Arica and "Irregular Triangle"22
The port works project in Arica (Fig. 9) concluded in July 1925 at an estimated cost of $\$ 367,000$ after almost three years of construction. This cost did not include the price of recently ordered equipment from Germany, which consisted of new electric cranes. While the port waited for the arrival of the improved cranes, to maintain the work at the docks three steam powered cranes were used. The Compania General de Construcciones at this point was responsible for the construction of a reinforced concrete building that contained the office of the captain of the port, located

at the entrance of the old pier, and rooms for luggage storage and inspection of passenger luggage at a cost of 452,000 pesos.

During this timeframe the enhancement of the streets occurred in the port city through the AngloChilean Asphalt Company located in Santiago. The terms of the agreement called for "15,000 square meters of asphalted concrete pavement." Consul Egmont C. von Tresckow reported the roads within Arica were "very narrow quite a number can be thus improved." In addition to the paving of streets in the city, concrete sidewalks were to be constructed as well. Prior to 1925, "an appreciable number of streets have been supplied with concrete sidewalks ... that had none previously." ${ }^{23}$ As with Antofagasta, the improvement of streets within the city of Arica afforded manufacturers the ability to transport materials with greater ease throughout the city. These improvements at the ports of Arica and Antofagasta were additionally supported by connecting the cities with a series of highways in each of their respective provinces, thus further explaining the improvement of streets within the cities and the improvement of ports.

\section{The Expansion of Highways in the Norte Grande}

As demonstrated by the improvement of streets within in the cities of Arica and Antofagasta, the Chilean state recognized the need to enhance and expand the highway system in the country to better connect the region to the metro pole. In the province of Antofagasta construction of the roads in the region were temporarily suspended, attributed to insufficient funds that could be appropriated by the Chilean government. Although, engineer Señor Juan Carabantes San Roman reported to Vice Consul Ben C. Matthews the Department of Antofagasta collected $\$ 558,940.20$ in new taxes. Matthews expressed the belief that as a result of the newly acquired funds from taxes, "work on the new highways in this province [Antofagasta] will be renewed at an early date." The primary concern was to continue the process of building the highway from Antofagasta to Hauytiquina, roughly two hundred miles away, near the border of Argentina. At the time of the report, roughly 50 miles had been built, connecting Antofagasta and "the station of Cuevitas, near Baqedano, and about the same distance had been finished from Calama to San Pedro de Atacama." This new highway proved of significant importance in conjunction with the

\footnotetext{
${ }^{22}$ Accessed June 20, 2012. http://www.mscchile.com/our_facilities/ports_arica.html. Although a contemporary picture, it provides the reader with the "irregular triangle protruding into the sea" that Consul Egmont C. von Tresckow reported in 1922.

${ }^{23}$ NAUS, RG59, M5144, reel 15, 825.15/9 "Improvements in the Province of Tacna," Consul Egmont C. von Tresckow to Department of State, April 26, 1926.
} 
proposed Antofagasta to Salta, Argentina railway. ${ }^{24}$

On August 1, 1922 with a median of 45 workmen the neighboring department of Tocopilla began construction of after several delays. This part of the thoroughfare traversed along the coast of Chile, a rocky region that caused development to be gradual and costly. The department worked with a budget of almost 118,000 pesos and had used $23,020.19$ pesos, which left the department with a balance of 94,068.88. By the end of 1922, funding for the highway in Antofagasta and the cities of Tocopilla and Taltal once again became severely limited. Appropriations for the construction of the highway in Antofagasta amounted to 493,669.57 pesos, however, the department in the city received only $276,850.15$. Roughly fifty employees continued to work on the international highway that was to connect the city of Antofagasta with Hauytiquina.

Although construction was maintained on the highway to Argentina, work on the additional highways in the province had come to a halt. This is attributed to the there "not being sufficient funds in the Treasury to meet appropriations." In Taltal, the department employed about twenty persons where construction was more laborious than the section in Tocopilla, due to "the rock obstructions." There was an appropriation of 56,137.56 pesos for the construction of the road. Only 8,302.20 pesos were spent on construction up to this point, but as the Fiscal Treasury possessed a deficit the balance was not available for use. Señor Juan Carabantes San Roman, the engineer in charge, declared a stoppage of work would be the next step if additional funds could not be procured. ${ }^{25}$ These issues with funding for public work projects coincide with one of several downturns in nitrate production. The economic downturn is illustrated by the lack of revenue generated by taxes received from nitrate (Fig. 10). The disbursement and lack of funds in the province of Antofagasta created several issues with the development of roads within the region, but Arica's roads appeared to receive the necessary funds for construction.

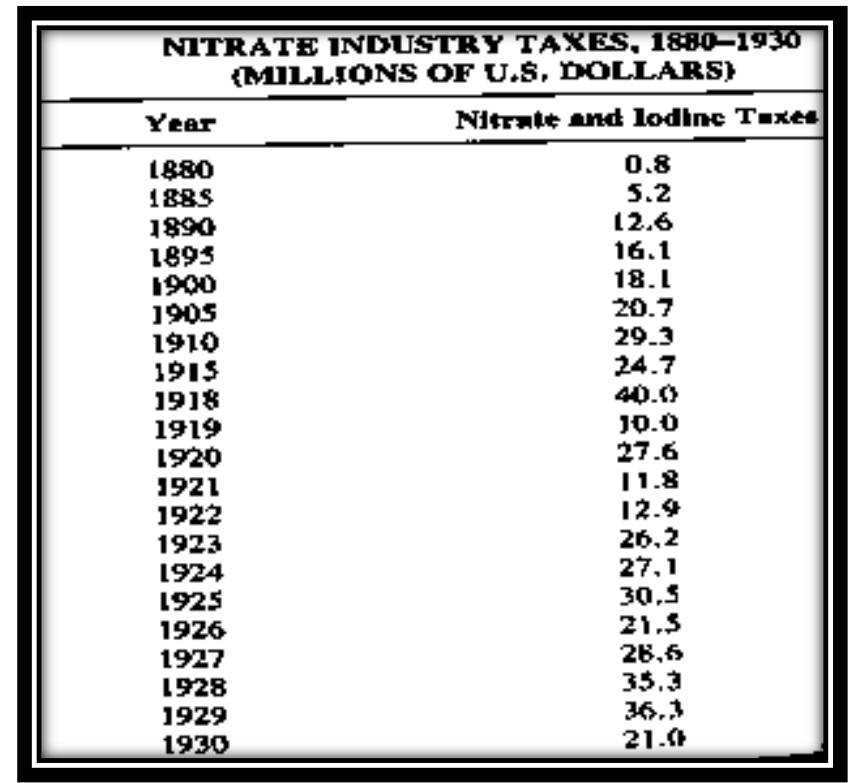

Figure 10: Table of Nitrate Industry Taxes ${ }^{26}$
In Arica, engineers from Franke Julian \& Cia oversaw the construction of a road under the slogan "Only Chilean Labor and Material." In spite of the arduous task of constructing the road through the mountains, the lack of rain fall in the region provided a safe working environment, as the engineers did not have to face the task of taking "provisions against mountain streams, floods, landslides, or other similar dangers incident to ordinary building in mountainous regions." Frequent blasting was required for the construction of the motorway, but due to the highly abundant cheap labor the firm did not purchase contemporary machinery for the movement of debris. In addition to their wages of five pesos a day, the workers were provided a "camp at Quilla and Palquilla ... in which no one is made to feel the want of medicines and food nor

\footnotetext{
${ }^{24}$ Ibid, 825.154/4, "Highway Construction," Vice Consul Ben C. Matthews to Department of State, May 30, 1922.

${ }^{25}$ Ibid, 825.154/6, "Highway Construction in Province of Antofagasta (Chile)," Consul Stewart E. McMillen to Department of State, February 9, 1923.

${ }^{26}$ Carmen Cariola, and Osvaldo Sunkel, "The Growth of the Nitrate Industry and Socioeconomic Change in Chile, 18801930," in The Latin American Economies, ed. by Roberto Cortés and Shane J. Hunt (New York and London: Holmes and Meier, 1985), 202.
} 
is there any reason for the workmen to make the slightest complaint." ${ }^{27}$ The road designed was 66 miles long and twenty feet wide to replace the highly dangerous footpath from Tacna to Tarata. However, the road was designed for "two wheeled carts," but with the capabilities of supporting military movement, thus making the northern region of Tacna "accessible to artillery."

Furthermore, the aim of the government appeared to be to employ many of the newly laid off nitrate workers from the south, where at this point four hundred had employment. An additional six hundred workers were to arrive at the beginning of May, as result of the decrease of production in the nitrate fields and increase layoffs (Fig. 11).

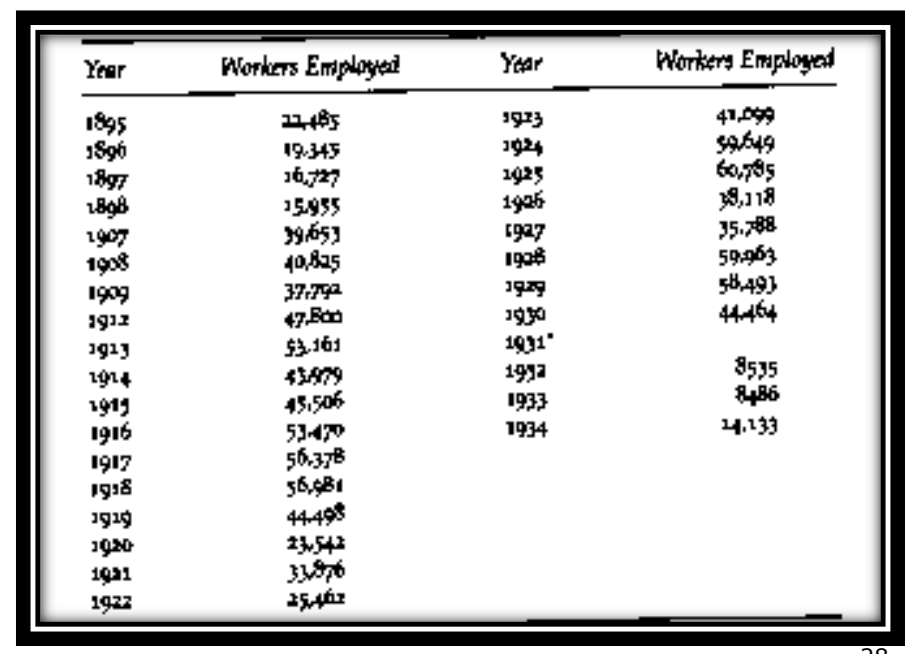

Additionally, the Chilean government at this time decided not to purchase expensive machinery for the development of the new road, attributed the abundance of cheap labor. Consul Egmont C. von Tresckow reported that engineers from Franke Julian y Cia proposed a budget of three million pesos for construction of the thoroughfare, this included the transferring of labor from Southern Chile "by steamer" estimated at 120,000 pesos, or 120 pesos per person.

Figure 11: Table of Workers Employed in Nitrate ${ }^{28}$

An estimated time of completion was one year from the time of the report, approximately $1923 .{ }^{29}$ Government officials not only concerned themselves with connecting the norte grande through roads and highways, but also connecting the region to Santiago.

In response to a recently returned delegation from the Highway Congress in the United States, the First National Highway Congress was held from April 12 to the 19, 1925 in Santiago. The congress was comprised of the automobile associations from Valparaiso and Santiago, in addition to the Chilean Federation of Highway Education, who supported the idea of a National Road system that was maintained and improved by the government. The commission strongly desired the acceptance of such a proposal for a national highway as quickly as possible, and that the procurement of funding should commence soon. Subsequently, the committee believed a request of a loan in the amount 150,000,000 Chilean paper pesos for 3,400 kilometers of road to be built within ten years, and "at the commencement of this plan a longitudinal road from La Serena, in the Coquimbo Province, to Puerto Montt, in the Llanquihue Province, and such others would united this main road with the large maritime cities [Arica and Antofagasta for instance] would be considered a national road."

To ensure the appropriate funding necessary for this endeavor it was proposed that finance for 50 percent of the cost should be through taxes "to be arranged for annually in the budget until the amortization be completed, the balance to be financed by new and special taxes to fall upon those most directly benefited by the highways." Additionally, an increase on import duties was suggested

\footnotetext{
${ }^{27}$ NAUS, RG59, M5144, reel 15, 825.154/9, "Completion of Road from Tacna to Tarata, Province of Tacna," Consul Egmont C. von Tresckow to Department of State, December 1, 1923.

${ }^{28}$ Loveman, Chile; The Legacy of Hispanic Capitalism, 170.

${ }^{29}$ NAUS, RG59, M5144, reel 15, 825.154/2, "Construction of a Public Road Tacna to Tarata, Chile," Consul Egmont C. von

Tresckow to Department of State, March 24, 1922.
} 
for the second half of the expenses, as well as new taxes on other sources such as; "petroleum, gasoline, tires and automobile spare parts, vehicles, minerals and ores exported, tolls on bridges and roads, each kilogram of animals killed in slaughter houses, on properties (government and private)." However, General Consul C.F. Deichman was skeptical about the ability of country to carry out the plan, due to the financial situation of country, although Deichman believed the completion of a national highway "would be of considerable benefit to the country." Consul Deichman further stated that the Chilean government had "already a heavy burden of taxation on commerce and with recently heavy increased rates on business of various kinds it seems that the burden of raising enough revenue to care of the additional loan of 150,000,000 pesos would not be justifiable for some time to come, notwithstanding the need of

good roads in Chile." 30

Additional diplomatic reports at this time to the United States, as far as the author is able to ascertain at this point, do not indicate whether or not the congress in Chile carried out the plans to enhance and construct the additional highways. But what is certain is that the government continued to receive requests for such action. For instance in 1927, the Chilean government received an appeal for the appropriation of 27,000,000 pesos for the improvement of "the most important roads leading into the capital." This was submitted due to most highways being impassible at certain points of the year and many needed repair, however, funding was limited at this point. Yet the desire to continue the building of roads in Chile is evident, and Consul Collier stated "the development of the country and stimulation of home industries that the this important question must be one of the first to be taken into consideration. ${ }^{131}$ In addition to the abovementioned request, an additional plea was made in December of 1927 for an increase in funding. These movements were directed "to stimulate national products," due to "various agricultural and industrial organizations [that] have positioned to hasten the construction of better roads, thus lowering the cost of transportation. ${ }^{32}$

\section{The Implications of Development in the Norte Grande}

The geography of the norte grande presents "few opportunities for port development," as "for hundreds of monotonous miles, the Coast Range forms a barren wall between 3000 feet and 6000 feet, plunging steeply into the Pacific." ${ }^{133}$ In addition to this, the region is so barren there are "weather stations that have never recorded rainfall," and "includes a desert more barren than the Sahara. ${ }^{34}$ As result, these geographical obstacles left the area with minimal infrastructure, and limited agricultural resources and ultimately necessitated large public work projects to ensure "a supply of consumer goods for the population of the Norte Grande, a desert region in which agricultural development was almost nonexistent." To do so, construction of this infrastructure required the movement of population to ensure the development of roads, and processing nitrates. ${ }^{35}$ Thus transporting materials to and from the norte grande through the enhancement of the ports Arica and Antofagasta, and roads can be seen as a means to connect irrigated valleys to the city centers to encourage additional development of the region.

Although Chile had possessed Tarapacá and Antofagasta since 1883, it was not until September 1910 that the Chilean government enacted a law creating the "Commission of

\footnotetext{
${ }^{30}$ Ibid, 825.154/10, "Certain Recommendations of the First National Highway Congress," Consul-General C.F. Deichman to Department of State, May 12, 1925.

31 Ibid, 825.154/16, "Improvement in the highways throughout Chile," Collier to Index Bureau, September $10,1927$.

32 Ibid, 825.154/17, "Minister of Fomento has asked the Minister of Treasury for additional funds for road construction," Collier to Index Bureau, December 12, 1927.

33 J. Valerie Fifer, "A Desert Frontier in Transition," the Geographical Journal, vol. 130, no. 4 (December 1964): 507, accessed June 16, 2012, http://www.jstor.org/stable/1792262.

${ }^{34}$ Loveman, Chile; The Legacy of Hispanic Capitalism, 19.

${ }^{35}$ Cariola and Sunkel, "The Growth of the Nitrate Industry," 140.
} 
Ports," and "authorized it to study a general plan of port development." By 1911, the commission reported the movement of cargo tonnage at each port in Chile. The ports of Antofagasta, Arica, and Iquique placed first, fourth, and sixth in net registered tonnage. Additionally, the Commission of Ports stated that the ports of Arica and Antofagasta were of "continental importance, inasmuch each of them is the terminus of an international railway," and "each of these ports is the outlet of a very important zone of attraction which assures it a great future development. ${ }^{\prime 36}$ Yet, the need to improve the ports of the norte grande was evident due to methods of handling modern ships, transporting cargo to the docks, and the roads that connected the various towns in the region. If Chile wanted to maximize the potential growth of the region, which coincided with the opening of the Panama Canal in 1914, it would be essential to improve their means of transporting goods in the ports to contribute to lower shipping costs.

The port of Antofagasta received special attention from the government as the harbor presented a valuable opportunity to develop "accommodations and facilities second to none on the Pacific Coast of South America," as the bay was "in a great half circle." This desirable combination afforded the possibility that "with protection from the weather the works might be enlarged and extended almost indefinitely at comparatively small cost, once the now contemplated works are completed. ${ }^{\prime 37}$ Furthermore, Antofagasta possessed two international railways with Bolivia, one to

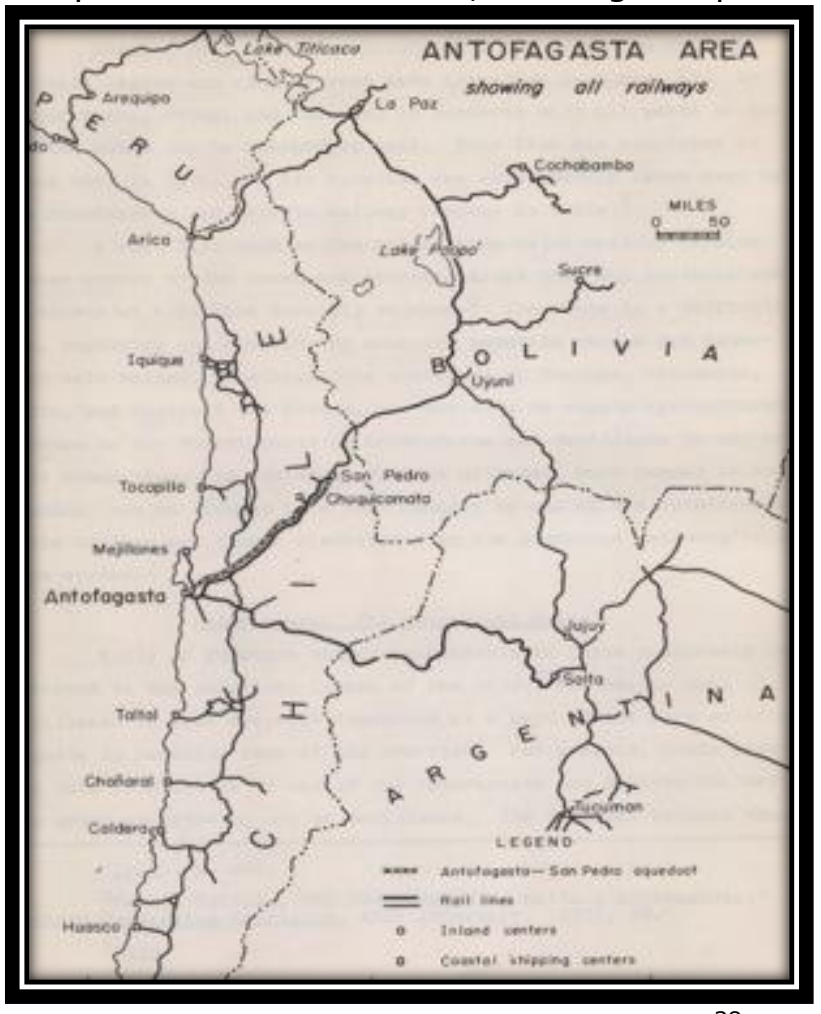

Oruro and La Paz. The proposal of a railroad to Salta, Argentina, further enhanced the prestige of the port (Fig. 12). Intercontinental trade proved to be the determining factor in renovating Antofagasta, and Arica. The port works of Arica additionally proved important to the plans of the Chilean administration due to the Arica to La Paz Railway that provided Bolivia with one of two ways of accessing the Pacific Ocean, the other being Antofagasta. Despite the Commission of Ports report in 1911 stating the importance of Arica to the Chilean state, work on the port was not noted by the United States until 1922. This account illustrated the need to streamline the port works, when Consul Egmont C. von Tresckow reported on how materials were transferred to and from the vessels. For instance barges and lighters were filled with the cargo to be transported from the ships, anchored in the bay, to the docks.

Figure 12: Map of International Railways ${ }^{38}$

\footnotetext{
${ }^{36}$ NAUS, RG59, M5144, reel 15, 825.156/3, "Chilean Port Improvement Works," Consul Stewart E. McMillen to Department of State, August 21-25, 1924.

37 Ibid, 825.156/40, "The Port Works of Antofagasta, Chile," Consul of Class 6 Stewart E. McMillin to Department of State, November and December, 1922.

${ }^{38}$ William Joseph Smole, "The Functions and the Functional Organization of the Ports of Rosario, Argentina and Antofagasta, Chile," (master's thesis, the University of Chicago, 1955), 57. The Antofagasta to Salta Railroad was not completed until 1948.
} 


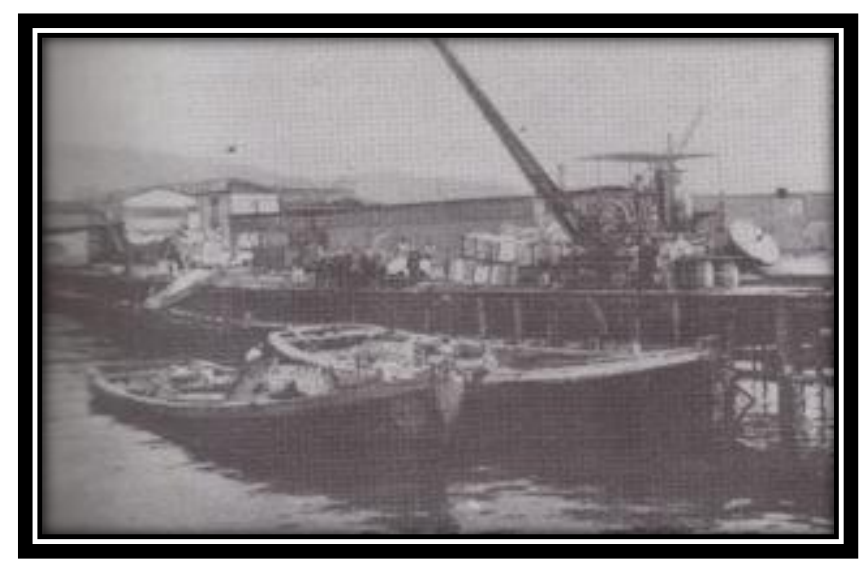

Figure 13: Photo of Barges and Cranes ${ }^{39}$
Subsequently a crane moved the cargo from the barges, or lighters, onto the trains for shipping (Fig. 13).

In addition to the "old fashioned dock facilities" one could find at the piers four cranes each with a limited capacity. As result of the limited lifting abilities of the cranes, cargo frequently stayed on the barges and lighters for several days. To improve the transfer of materials the Department of Railroads ordered; "two three ton, two five ton, and one twenty five tone, electric cranes."

In addition to the new cranes the construction of a new pier was commissioned, as at this point of the three piers one was completely out of commission and the other two were so insecure vessels could not dock on them during any inclement weather. With the older cranes, and only two moderately functional piers, the Port of Arica moved approximately 130,000 metric tons on average per year. With the suggested upgrades by the Commission of Ports it was estimated that there would be an increase to 215,000 tons of cargo a year. Besides the transferring of cargo by lighters and barges, the low movement of materials can be attributed to the low number of freight cars of the Arica to La Paz Railway Company, who proposed additional cars to be built upon completion of the pier. The improved port facilities included "a naval station and a large basin for merchant vessels." 40

To further demonstrate the necessity to remodel the ports of Chile, Consul Homer Brett also emphasized the state of the port of Iquique, who transported material in a similar manner to Arica and Antofagasta. This was attributed to the lack of depth in the port that caused ships to dock further out in the bay where roughly 350 lighters and barges with "an average capacity of 35 tons each" transferred materials from the vessels to their respective piers. Each pier had multiple steam cranes, with lifting capabilities of five tons, and connected with railways leading to the various warehouses, as well as the mainline of Nitrate Railways Ltd. The railroad connected with "all the 86 nitrate plants of the interior." The improvements at the port in Iquique not only stemmed from the need to maximize the movement of cargo, but to increase the importation of goods. Iquique relied on a variety of imports from various sections of Chile. This is illustrated by the surrounding landscape that is "absolutely desert and produces nothing for the sustenance of animal life. Fruits and vegetables are brought from Tacna and in less quantity from Pica; flour, forage and meat animals from Southern Chile." Importation of rations limited a buildup of supplies and was "never large enough to supply the town for more than three weeks if communication were interrupted." ${ }^{41}$ Upgrading Chilean ports proved to be a difficult task, and took a number of years to occur, attributed to a variety of factors, such as nitrate tax revenue and political issues, as previously mentioned.

At the beginning of 1926, Consul von Tresckow reported on the "unusual number of improvements" in the province of Tacna. Von Tresckow informed the Department of State of the completion of the new pier at Arica occurred in July of 1925. In addition to the finished pier, the report states the construction of a new tourist hotel for the Arica to La Paz Railway by the construction firm Franke,

\footnotetext{
39 Vargas, et. al, Una Historia en Imágenes, (Antofagasta: Universidad de Chile, 1979), 95.

40 NAUS, RG59, M5144, reel 15, 825.1561/2, "Harbor Improvement at Arica, Chile," Consul Egmont C. von Tresckow to State Department, March 30, 1922.

${ }^{41}$ Ibid, "Report On Harbor Facilities at Iquique Chile," Consul Homer Brett to Department of State, August $22,1922$.
} 
Julian \& Cia, "as Arica lack[ed] good hotel accommodations." 42 The Franke Julian \& Cia frequently worked with the Chilean government and possessed offices in Santiago, Valparaiso, Tacna and Arica. This Chilean company greatly "benefited from contracts from the Chilean state to build roads, public buildings, irrigation systems and so on."43 In addition to the tourist hotel in Arica, which provided "modern equipment with spacious lounging and social rooms," the firm constructed a large frame hotel for 250 guests for plebiscitary voters inside the recently reinforced Velasquez Barracks for the artillery regiment. The hotel was completed in time for the Tacna-Arica arbitration commission composed of the Chileans and Americans. Besides the hotel in the barracks, the renovation of the residence for the governor of Arica, as well as the dwellings "to be occupied by General Pershing and the principal American and Chilean plebiscitary officials" were finished at this time.

Government involvement in Arica included the purchase of the light company in Arica in the middle of 1925 for one million pesos, which was previously owned by Alumbrado Electrico de Arica.

Subsequently the Chilean government renovated and improved the establishment, as two months prior to the plebiscite the plant broke down. Since that time the government ran the light company "in conjunction with the railroad shops of the government owned Arica - La Paz Railway." The railway company owned the newly constructed pier that used electric cranes so the "idea of assuming charge of the city lighting seems very feasible." In spite of the substantial growth during this period the other town of the province, Tacna, saw little improvement. Franke Julian \& Co. built a new frame hotel for 500 guests for the Chilean voters during plebiscite, despite the fact that Tacna experienced a 50 percent decrease in population; originally 20,000 had resided in the city. In addition to these improvements in the region, a new radio station was built by an EnglishAmerican firm in 1925 and was deemed "a great importance for the district." The structure was built quickly for the plebiscite period August 2, 1925 and had a capability of reaching Santiago. ${ }^{44}$ Despite the lack of development in the city of Tacna, this did not undermine its role in the advancement of the region, as the Chilean government attempted to bring the small villages of the Arica-Tacna area within closer proximity to the state.

The city of Tacna is located approximately forty miles away from the Port of Arica by railroad in the Province of Tacna. Roughly thirty miles northeast "in a direct line" of the city situated in an irrigated valley one could find the town of Tarata, which was only accessible by "a pack mule trail." This "trail" traversed 56 kilometers and could only accommodate "two wheeled wagons." Yet the importance of the new road, as dictated by Consul Egmont C. Von Tresckow, "will be ... practicable for autos." ${ }^{\prime 4}$ Tarata's population consisted of approximately 1,100 inhabitants, who were all considered farmers. The town could be found in a rural setting that covered an area of 6,032 square kilometers and located high in the mountains, estimated to be located at 3,052 meters above sea level. Thus, Tarata found itself surrounded by mountains ranging "from 4,200 to 5,500 meters above sea level and encircling the former department in the shape of horseshoe whose open ends face the Northwest mountain chains of only 2,500 to 3,500 meters above the sea."

Several factors contributed to the construction of the road in the region. First one must take into consideration not only the poor accessibility to Tacna, but that the town of Tarata was within eight kilometers of the Sama River, the border with Peru (Fig. 14). The local inhabitants, rather than

\footnotetext{
42 Ibid, 825.15/9 "Improvements in the Province of Tacna," Consul Egmont C. von Tresckow to Index Bureau Department of State, April 26, 1926.

${ }^{43}$ William E. Skuban, Lines in the Sand; Nationalism and Identity on the Peruvian-Chilean Frontier (New Mexico: University of New Mexico Press, 2007), 272FN.

44 NAUS, RG59, M5144, reel 15, 825.15/9 "Improvements in the Province of Tacna," Consul Egmont C. von Tresckow to Department of State, April 26, 1926.

${ }^{45}$ Ibid, 825.154/2, "Construction of Public Road Tacna to Tarata, Chile," Consul Egmont C. von Tresckow to Department of State, March 24, 1922.
} 
traverse the dangerous path to Tacna, where many fell to their death, traded in large part with Peruvians. The road would then enable these precious commodities to be sent to the center of the province of Tacna for trade with Chileans, and to stimulate agricultural development in the territory. The sentiment by von Tresckow revolved around the idea that if Tarata began to send produce to Tacna, then with the increased demand in city center the farmers of Tarata would increase the productivity of their region. ${ }^{46}$ This is imperative "since the Norte Grande possessed practically no agricultural resources, and nearly all the inhabitants lived in villages or smaller localities with no possibilities for producing their own food, the whole population depended almost entirely on supplies from outside."47

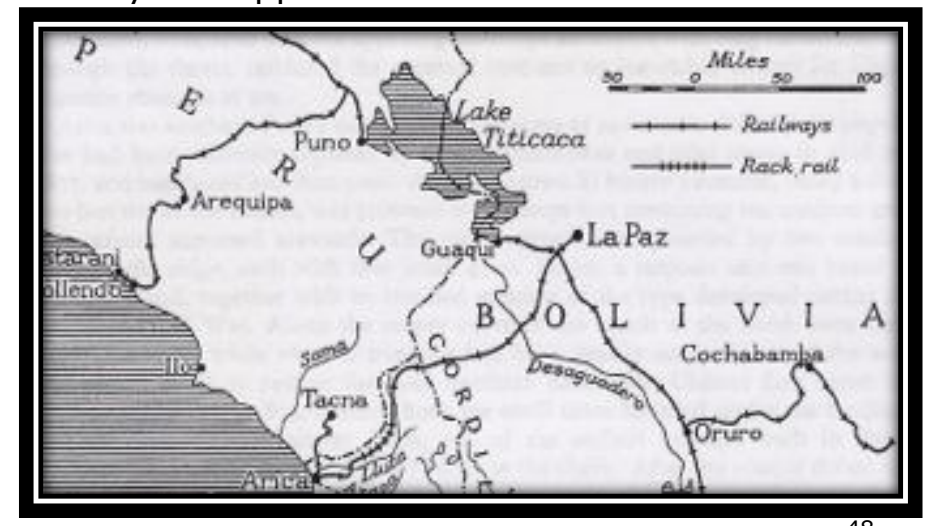

Figure 14: Map of Peru and Bolivia, Sama River ${ }^{48}$
In addition to the road to Tarata, the Chilean government agreed to terms with the Franke Julian y Cia to construct a road to the town of Putre. Similar to Tarata, the people of Putre traveled along a "mountain trail ... at great danger to life and limb, so that the produce of the irrigated land around Putre cannot be marketed." It was suggested that the road would benefit the locals greatly. The new proposal proposed the "new mule trail" would measure three meters wide. Construction was to be conducted by roughly one hundred men

from the southern nitrate region in $1923 .{ }^{49}$ The newly designed road for Putre could plausibly accommodate an automobile. One should take this into consideration as in Tarata "the [new] road will also serve as a military highway as it renders the Tarata section accessible to artillery and wagon trains or trucks."

Consul von Tresckow reported on December 1, 1923 the completion of the new road from Tacna to Tarata, which covered a distance of slightly over one hundred kilometers and was conducted by Franke Julian \& Cia. The Intendente (governor) of the province, the governor of the Department of Arica, and other civil officials inaugurated the road with a march by the provincial brigade garrisoned at Tacna. Despite the steep grades the march by brigade from Tacna to Tarueache, 70 $\mathrm{km}$ from Tacna, without incident. This is of importance as two points were known for their danger, and this was at the highest points at 25 and $60 \mathrm{~km}$ posts. However, due Chief Engineer Don Eleodor Ramos' familiarity with the region it enabled him to devise a more than appropriate plan to ensure a safe route. Following the ceremonial opening of the new road, trucks, autos, and artillery arrived in Tarata, this was the first time the town had seen mechanized vehicles. According to Consul von Tresckow, the Aymara Indians "regarded them with awe and apprehension." Additionally, the new road "was to be solely for equestrians and pack mules," but the Chilean government altered the plans for the region. In addition to the military and for the purposes agricultural development of Tacna, the road provided the opportunity to connect "Taratanians into

\footnotetext{
${ }^{46}$ Ibid, 825.154/9, "Completion of Road from Tacna to Tarata, Province of Tacna," Consul Egmont C. von Tresckow to Department of State, December 1, 1923.

${ }^{47}$ Cariola and Sunkel, "The Growth of the Nitrate Industry," 151.

${ }^{48}$ Fifer, "A Desert Frontier in Transition," 508. This map helps to demonstrate the location of the Sama River in regard to Tacna, thus providing an approximation of the town Tarata. The map illustrates contemporary boundaries, as prior to the Treaty of Lima of 1929 Chile considered the Sama River to be the boundary as puportedly dictated by the Treaty of Ancón of 1883.

49 NAUS, RG59, M5144, reel 15, 825.154/3, "Construction Work in Tacna Province," Consul Egmont C. von Tresckow to Division of Latin American Affairs Department of State, May 24, 1922.
} 
closer touch with the outside world." 50

\section{Conclusion}

This narrative provides the details on the material aspect of the enhancement of ports and construction of roads in the norte grande. Primarily, this is the perspective of the United States on the increased advancement of infrastructure in northern Chile. But to better comprehend the magnitude of "large capital investment; the displacement of a considerable number of people; the building of broad infrastructure of railroads, telegraph services, and urban and port facilities; the expansion of housing in the nitrate area and on the coast, ${ }^{\prime 51}$ we must take into consideration the viewpoints of Bolivia and Peru to the modernization of region. Due to the limited resources in the United States, and time constraints, it was highly implausible to provide the stance of said countries, as well as the many laborers who contributed to the expansion of ports and roads. As I move forward in my research during my PhD, access to additional resources in the National Archives in Chile, Bolivia, and Peru will only enhance the human aspect and political implications of this piece, while at the same time demonstrating the impact of the mass movement people and its subsequent influence on the customs and cultures of the inhabitants of the area.

\footnotetext{
${ }^{50}$ Ibid, 825.154/9, "Completion of Road from Tacna to Tarata, Province of Tacna," Consul Egmont C. von Tresckow to Department of State, December 1, 1923. Consul Tresckow does not refer to the Aymara directly, however, in William E. Skuban's work, the author highlights that the people of the Tacna area are Aymara.

${ }^{51}$ Cariola and Sunkel, "The Growth of the Nitrate Industry," 140.
} 


\section{Bibliography}

\section{Primary Sources}

NAUS, RG59: Records of the Department of State relating to the Internal Affairs of Chile (M5144) 1910-1929, reel 15.

\section{Secondary Sources}

Blakemore, Harold. "Chile." In Latin America: Geographical Perspectives. edited by Harlod Blakemore and Clifford T. Smith, 475-566. London: Methuen \& Co Ltd, 1971.

Cariola, Carmen and Osvaldo Sunkel. "The Growth of the Nitrate Industry and Socioeconomic Change in Chile, 1880-1930." In The Latin American Economies, edited by Roberto Cortés and Shane J. Hunt, 137-254. New York and London: Holmes and Meier, 1985.

Fifer, J. Valerie. "A Desert Frontier in Transition." the Geographical Journal, vol. 130, no. 4 (December 1964): 507-518. Accessed June 16, 2012. http://www.jstor.org/stable/1792262.

Hickman, John. News from the End of the Earth: A Portrait of Chile. New York: St. Martin's Press, 1998.

Loveman, Brian. Chile: The Legacy of Hispanic Capitalism. Oxford: Oxford University Press, 2001.

--------. Struggle in the Countryside: Politics and Rural Labor in Chile, 1919-1973. Bloomington: Indiana University Press, 1976.

Nunn, Fredrick M. Chilean Politics 1920-1931; The Honorable Mission of the Armed Forces. Albuquerque: University of New Mexico Press, 1970.

Ramírez, Isaac Arce. Narraciones Históricas de Antofagasta. Antofagasta, 1930.

Skuban, William E. Lines in the Sand: Nationalism and Identity on the Peruvian-Chilean Frontier. Albuquerque: University of New Mexico Press, 2007.

Smole, William Joseph. "The Functions and the Functional Organization of the Ports of Rosario, Argentina, and Antofagasta, Chile." Master thesis, the University of Chicago, 1955.

Vargas, Juan Panades, Floreal Recabbren Rojas, Antonio Obilinovic Arrate, and Alfonso Calderon Squadritto. Antofagasta: Una Historia en Imágenes. Antofagasta: Universidad de Chile, 1979. 